\title{
In Memoriam: Nils-Axel Mörner (1938 - 2020)
}

\author{
Rabbe Sjöberg \\ Bodviksvägen 14, 91342 Obbola, Sweden
}

Nils-Axel Mörner (1938-2020) is no longer among us. On October $16^{\text {th }}$ he left us after a very short illness. Niklas, as he was called by friends, has left a huge emptiness behind him. He had a great knowledge in many topics. He was a man of great thoughts, solid truth seeking and integrity. He showed us to work with eyes and measure, not with models. Empirical evidence was his law. He was a man of absolute honor and a wonderful friend. He was also a merry chap, which all who knew him, heard his lectures or joined him on excursions could experience. Our thoughts goes to his wife Ulla, his children, and grandchildren.

Niklas's 487-pages long doctoral thesis "The Late Quaternary history of the Kattegatt Sea and the Swedish West Coast: deglaciation, shorelevel displacement, chronology, isostasy and eustasy" was published in 1969. It was considered so brilliant that he received a life-time appointment at Stockholm University very early in his career. In 1977 he organized the international conference on Earth Rheology and Late Cenozoic Isostatic Movements. This was the ground for all that was to come. In 1991 his research center on Paleogeophysics and Geodynamics (P\&G) was initiated. Niklas was the head of this department until retiring in 2005. After that, $P \& G$ became his private institute. Between 1981 and 1989 he was the chairman of INQUA Neotectonic Commission, and in 1999-2003 in the INQUA Sea-Level Commission. He was a world leading specialist on coastal studies and visited and investigated more that 50 controversial sea level sites around the globe. He had a very broad knowledge and engagement, which also included pseudokarst. As a collaborator of the Pseudokarst Commission, he co-organized in 2011 the $2^{\text {nd }}$ Granite Cave Conference in Sweden with a four days long excursion along the northern Swedish Coast. Over his long career, he published exactly 700 papers covering a variety of topics. As a scientist he was active until the very last days of his life.

In the following, I will concentrate on his pseudokarst research and how he and I solved how and when a majority of Swedish bedrock caves were formed.

In 1993 I asked Niklas to be my doctoral thesis advisor on the presumably seismo-tectonically formed bedrock caves I was researching. The thesis "Bedrock caves and fractured surfaces in Sweden, occurrence and origin" was successfully defended in November
1994 and became the starting point for the Boda Cave Project (1997). The field work was concentrated to the Hudiksvall region along the Baltic Sea coast, where Boda Cave, Sweden's largest boulder cave is located. This project improved our understanding on how isostatic land uplift and the processes connected to that occurred. Among many other things we showed that the isostatic uplift rate reached $300 \mathrm{~mm} /$ year along the edge of the inland ice 9,600 years ago, much more than earlier anticipated. This huge land uplift caused violent earthquakes. We found how a majority of the boulder-caves in Sweden were formed by these gigantic, early post-glacial earthquakes, often followed by explosions of methane hydrate, blasted the by glaciations polished hills into heaps of edgy boulders. However, we had a big problem understanding why so many of these earthquakes seemed to have occurred as late as $\sim 3,000$ years BP.

Within the frames of this project two international field trips were organized in 2000 and 2008. Both started in my home town Umeå and ended in Hovs Hallar in southern Sweden, the main site of Niklas's thesis from 1969. The first one was part of the INQUA Congress, whereas the second was organized in conjunction with the International Geological Congress in Oslo. In 2011 we organized the $2^{\text {nd }}$ Conference on Granite Caves in cooperation with the Pseudokarst Commission and the Swedish Speleological Society. This included a field trip from Nynäshamn, close to Stockholm, to the big boulder caves around the town

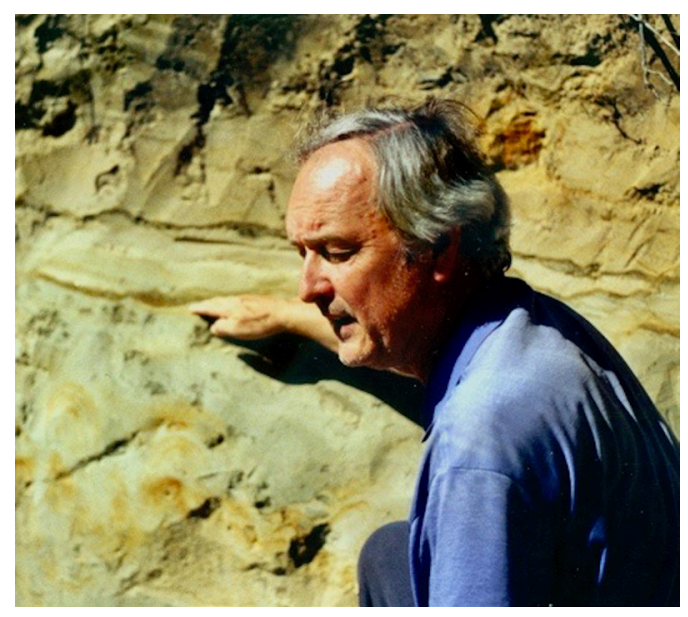

Nils-Axel Mörner explaining sediments during an excursion in 2004 (photo: R. Sjöberg). 
of Hudiksvall, mentioned earlier. The discussions and the knowledge gained from the participants helped developing the project. The number of published scientific papers connected to the project were numerous and our last one "Merging the concepts of pseudokarst and paleoseismicity in Sweden. A united theory on the formation of fractures, fracture caves, and angular block heaps" was published in the UIS International Journal of Speleology in September 2018 and tells the full history of our combined projects.

Niklas last fieldwork, just weeks before his death, was to find out about how the Kaali meteorite impact in Estonia formed a gigantic tsunami wave, which in the 1171 varve years BC (as he precisely measured in August 2020 in the varved clays on the banks of the Ångermanälven River in northern Sweden) devastated the Swedish coastline, initiated earthquakes and burning methane gas venting. This, according to Niklas, could be the background to what was called the "Ragnarök" (Harmagedon) in the Northern mythology.

The world has lost a great man, a great scientist, and a great Truth Teller. I will always remember my friend Niklas.

\section{Selected publications by Nils-Axel Mörner}

Mörner, N.-A., 1969. The Late Quaternary history of the Kattegatt Sea and the Swedish West Coast: deglaciation, shorelevel displacement, chronology, isostasy and eustasy. Sveriges Geologiska Undersökning, C-640, $487 \mathrm{p}$.

Mörner, N.-A., 1977. The Fennoscandian uplift: geological data and their geodynamic implication. Abstracts "Earth Rheology and Late Cenozoic Isostatic Movements" Symposium, Stockholm July 31 - August 3, 1977, p. 92-101.

Mörner, N-A., 2003. Paleoseismicity of Sweden a novel paradigm. A contribution to INQUA from its Subcommission on Paleoseismology at the $16^{\text {th }}$ International INQUA Congress in Reno, Nevada. Stockholm University, P\&G print, 320 p.

Mörner, N-A., Sjöberg, R., Audemard, F., 2008. Paleoseismicity and Uplift of Sweden. 33 ${ }^{\text {rd }}$ International Geological Conference, The Nordic Countries 2008, Excursion Guide 11, 109 p.

Mörner, N.-A., Sjöberg, R., 2011. Second International Conference on Granite Caves, Sweden, 2011. Excursion Guide. Sveriges Speleolog-Förbund, Svenska Grottor, $12,1-28$.

Mörner, N.-A., 2017. Methane hydrate in crystalline bedrock and explosive methane venting tectonics. Supplementary data. Earth-Science Reviews, 169, 202-212

Mörner, N.-A., Sjöberg, R., 2018. Merging the concepts of pseudokarst and paleoseismicity in Sweden: A a unified theory on the formation of fractures, fracture caves, and angular block heaps. International Journal of Speleology, 47(3), 393-405. https://doi.org/10.5038/1827-806X.47.3.2225 